\title{
SCENARIOAL APPROACH TO LABOR POTENTIAL MANAGEMENT OF PHARMACY NETWORK EMPLOYEES
}

\author{
Makarenko O. Kudiievska K. \\ Zaporizhzhia National University \\ Ukraine, 69600, Zaporizhzhia, Zhukovsky str., 66 \\ olenamak@gmail.com,kudik98@ukr.net \\ ORCID 0000 - 0003-1009-5122, ORCID 0000-0001-6313-8259
}

Key words:

cognitive modeling, fuzzy model, scenario, labor potential, motivation.
The article is devoted to the study of the problem of labor potential management employee. Under management is a purposeful influence on the employee in order to improve the quality of his work in order to increase the efficiency of the enterprise and increase its profits. It has been proposed to use a scenario approach in the management of labor potential at the microeconomic level. The main purpose of the scenario approach is to build scientifically sound scenarios for the development of economic phenomena and use them in the process of supporting management decisions. A step-by-step procedure for managing labor potential at the microeconomic level, which includes four stages: analysis of factors influencing the labor potential of the employee and building a cognitive model, collecting statistical information, assessing the individual level of labor potential based on fuzzy model, forming employee ratings based on individual assessments, development of scenarios of labor potential management at the macro level using a cognitive model. The proposed approach has been tested on the example of labor potential management of pharmacy network employees. The main factors influencing the level of labor potential of a pharmacy network employee have been determined. The fuzzy inference rule is used to calculate individual estimates of labor potential of employees. The model of management of labor potential of the employee of a drugstore network allows to make reasoned decisions concerning motivation of the personnel, and also to substantiate scenarios of management of the enterprise for increasing of level of labor potential of employees of a drugstore network. When developing scenarios for assessing the impact of factors on the level of labor potential of the employee in the dynamics of a simulation experiment using a pulse model.

\section{СЦЕНАРНИЙ ПІДХІД ДО УПРАВЛІННЯ ТРУДОВИМ ПОТЕНЦІАЛОМ ПРАЦІВНИКІВ АПТЕЧНОЇ МЕРЕЖІ}

\author{
Макаренко О.І. Кудієвська К. К. \\ Запорізький національний університет \\ Україна, 69600, м. Запоріжжя, вул. Жуковського, 66
}

\section{Ключові слова:}

трудовий потенціал, мотивація, когнітивне моделювання, імпульсна модель.
Стаття присвячена дослідженню тенденцій розвитку трудового потенціалу працівників аптечної мережі. Визначено поняття трудового потенціалу працівника. Розроблено модель управління трудовим потенціалом на мікроекономічному рівні на основі сценарного підходу 3 використанням методів імітаційного моделювання та нечіткої математики. Запропоновану модель апробовано на прикладі управління трудовим потенціалом працівників аптечної мережі. Визначено основні фактори впливу на трудовий потенціал працівника аптечної мережі. Оскільки більшість факторів, що впливають на трудовий потенціал працівника - якісні, для моделювання процесу управління трудовим потенціалом використано когнітивне моделювання та методи нечіткої математики.

Експертним методом визначено вагові коефіцієнти для кожного фактору. Використано метод нечіткого виведення для розрахунку точкових оцінок працівників. Розроблено модель управління трудовим потенціалом працівника аптечної мережі, що дозволяє обгрунтовано приймати рішення щодо мотивації персоналу та дозволяє обгрунтовувати сценарії управління підприємством для збільшення трудового потенціалу працівників аптечної мережі. Визначено основні етапи побудови моделі управління трудовим потенціалом на мікроекономічному рівні на основі сценарного підходу. Для оцінювання впливу факторів на рівень трудового потенціалу працівника в динаміці проведено імітаційний експеримент із застосуванням імпульсної моделі. Запропоновано сценарії управління трудовим потенціалом працівника. 


\section{Problem statement}

The efficiency of the enterprise depends on the level of its competitiveness, which, in turn, is determined by the labor potential of the enterprise. The realities of the current socio-economic situation repeatedly prove that there are negative trends of deterioration. It is associated with job satisfaction, which is determined by such factors as: working environment, remuneration, safety, etc. Thus, determining the "fair" amount of remuneration in order to increase the level of labor potential of the employee is an important component of the enterprise management process. The relevance of the topic is due to the fact that the assessment of labor potential allows to identify unrealized opportunities of the employee and on this basis to influence the effectiveness of his work, for example, through the use of motivation and incentives, which will ultimately lead to increased profits.

\section{Analysis of latest researches and publications}

Problems of labor potential management at the macro- and microeconomic levels were studied by the following domestic scientists: Mironova L., Blednykh A., Shevchenko S., Zhukevych S., Shostak L. and others.

Mironova L. [1] defines the concept of "labor potential of the employee", notes that modeling the management of labor potential of the employee - is a continuous process that requires constant analysis of the state of labor potential of employees and its compliance with the objectives of the enterprise.

Blednykh A. [1] in his research considers methods of assessing the labor potential of the employee, determines the coefficient of labor productivity, notes that the profitability of staff reflects the efficiency of labor resources and demonstrates what profit in UAH the company received per employee, determines the factors influencing the labor potential of the employee.

Melnychuk D. [2] considers labor potential at the macroeconomic level through the prism of human capital. The researcher proposed an author's approach to the interpretation of the content of labor potential as a criterion for assessing the human capital of Ukraine.
Mironova L. [3] defines the concept of "labor potential of the employee", notes that modeling the management of labor potential of the employee is a continuous process that requires constant analysis of the state of labor potential of employees and its compliance with the goals of the enterprise.

The main reasons for the low efficiency of the use of labor potential are presented in the works of Shevchenko S. [4] and proved the need to introduce flexible wages and employee motivation system.

The main problems in the formation of labor potential of enterprises are presented in the studies of Shostak L. [5] and it is recommended to use a multifaceted system of remuneration and incentives.

Despite the significant number of studies on labor potential management, the issue of improving the efficiency of enterprise management by activating the potential resources of the employee with the use of modern methods is insufficiently covered, which determines the relevance of the chosen research topic.

\section{Statement of objectives}

The objective of the article is to develop a step-by-step procedure for managing labor potential at the microeconomic level based on a scenario approach using simulation methods and fuzzy mathematics.

\section{Presentation of basic material of the research}

The management of labor potential of employees is a purposeful influence on the employee in order to improve the quality of his work in order to increase the profits of the enterprise. Positive, purposeful influence on the employee, in our opinion, is carried out by increasing motivation to work. To implement this task, the authors propose a step-by-step procedure for managing labor potential at the microeconomic level based on the scenario approach, which is presented in Fig. 1. The process of labor potential management at the microeconomic level consists of four stages.

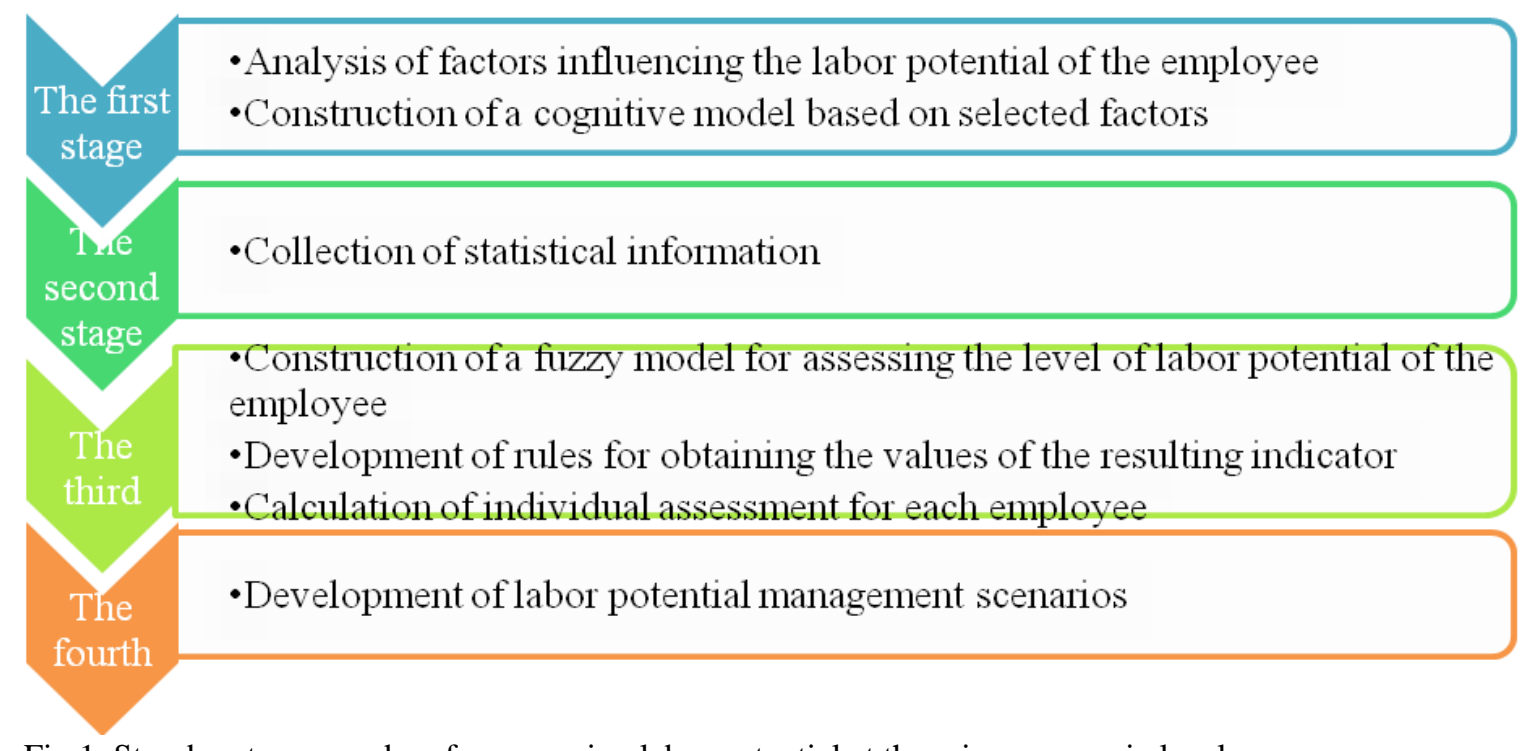

Fig.1. Step-by-step procedure for managing labor potential at the microeconomic level

Source: developed by the authors 
At the first stage, the analysis of factors influencing the labor potential of the employee and the construction of a cognitive model. To determine the influence of factors on the resulting indicator, it is advisable to use the method of cognitive modeling, which allows determining the influence of both quantitative and qualitative factors on each other.

The second stage of the labor potential management procedure is the collection of statistical information, the formation of an array of input data on selected factors.

At the third stage, a fuzzy model for estimating the level of labor potential of the employee is built. At the same stage, the rules for obtaining the values of the resulting linguistic variable "level of labor potential" are developed, and an individual assessment is calculated for each employee and on the basis of these assessments the rating of employees is formed. The higher the value of the individual assessment, the higher the employee's rating, the lowest the value of the individual assessment corresponds to the last place in the rating. The results of the employee rating can be used for various types of staff motivation, for example, to determine the material reward, salary increase, etc.

The fourth stage is the development of scenarios for managing labor potential at the macro level using a

Table 1

Coding of cognitive model factors cognitive model. The main purpose of the scenario approach is to build logical "stories", different and equally real options for future development. Thus, the scenario is not considered as a "rigid" plan, but acquires a certain flexibility that allows the company to adapt to different development options.

The scenario approach allows taking into account the influence of various factors that are uncertain. Building scenarios of possible development options in the future allows you to reasonably formulate strategic alternatives for each scenario. The proposed model of labor potential management at the microeconomic level based on the scenario approach was tested at the pharmacy network enterprises.

Thus, at the first stage the analysis of the factors influencing the level of labor potential is carried out. The analysis of this problem allowed to determine the following factors for pharmacy network employees: health, education, experience, age, workload, working conditions, ability to work with customers, employee turnover of the pharmacy, the availability of additional sales, the average check. At the same stage, a cognitive model of the relationship of factors influencing the level of labor potential of the employee, each factor is given a serial number (Table 1).

\begin{tabular}{|l|l|}
\hline The name of the factor & $v_{i}$ \\
\hline Health & 1 \\
\hline Education & 2 \\
\hline Experience & 3 \\
\hline Age & 4 \\
\hline Workload (Staffing) & 5 \\
\hline Working conditions & 6 \\
\hline Ability to work with clients & 7 \\
\hline Trade turnover & 8 \\
\hline Availability of additional sales & 9 \\
\hline Average check & 10 \\
\hline The level of labor potential of the employee & 11 \\
\hline
\end{tabular}

Source: developed by the authors

These factors are the vertices of the oriented graph in the cognitive model [6]. In this case, the level of labor potential of the employee is the initial variable, which is a direct and indirect influence of other factors. The causal relationships between the factors are determined and a set of graph arcs is formed.
In this case, the vertices of the graph have no weight, and the arcs are weighed according to the following rule: if an increase in the factor from which the arc emerges leads to an increase in the value of the factor in which it enters, the arc has a positive sign, and if it decreases, it has a negative sign [7]. Graphic representation of the cognitive model is presented in Fig.2.. 


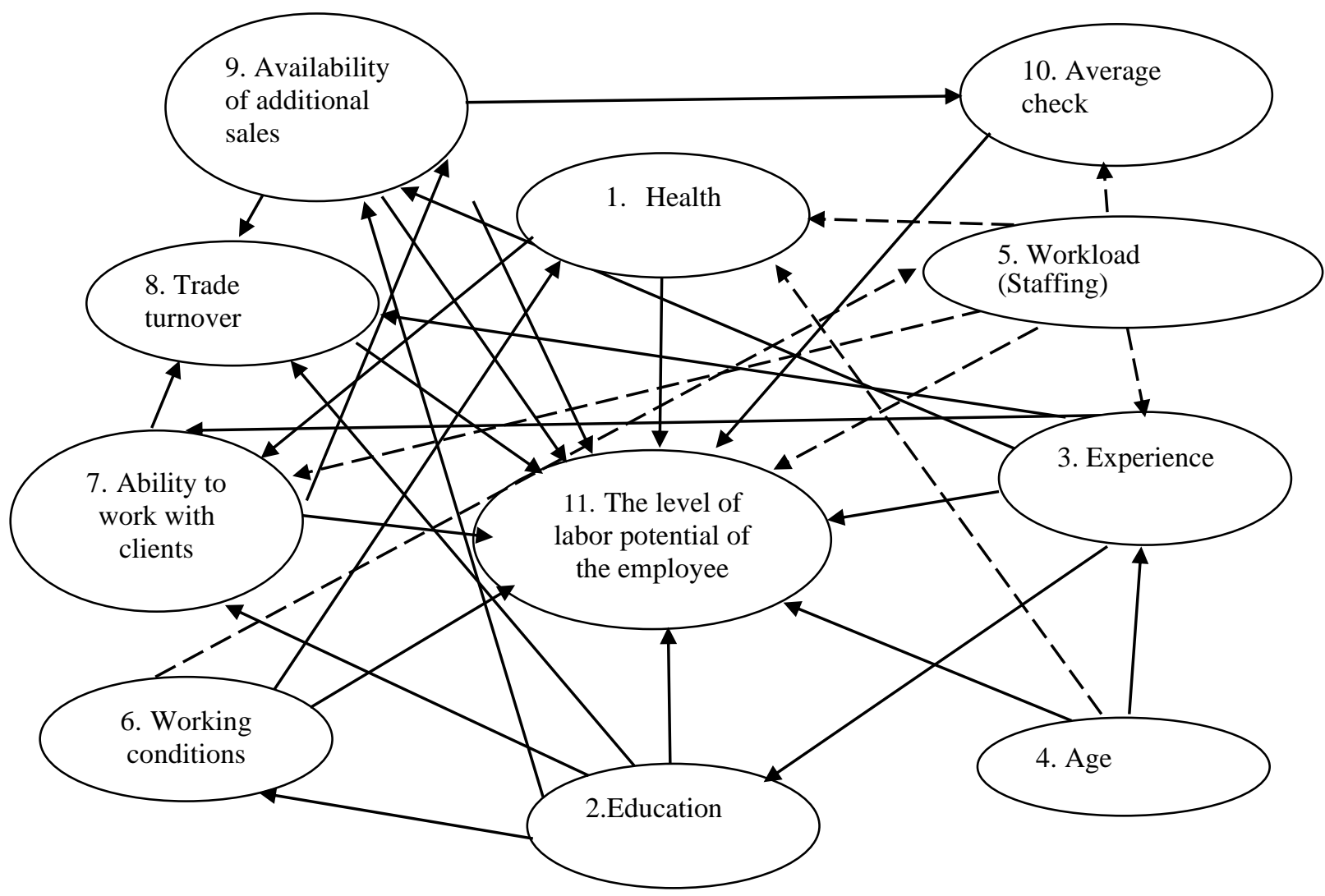

Fig.2 Cognitive model of influence on the level of labor potential of the pharmacy network employee Source: developed by the authors

At the second stage of labor potential management at the microeconomic level, statistical information was collected taking into account the definition of fuzzy indicators. An array of input data is formed according to the selected factors.

Definitions of fuzzy indicators that affect labor potential are presented in Table 2.

Table 2

Identification of fuzzy indicators that affect the level of labor potential

\begin{tabular}{|l|l|l|}
\hline Indicator & The essence of the indicator & $\begin{array}{l}\text { Linguistic } \\
\text { significance } \\
\text { of the } \\
\text { indicator }\end{array}$ \\
\hline Health status $\left(\mathrm{x}_{1}\right)$ & $\begin{array}{l}\text { Significance that shows how the employee assesses his health, whether he } \\
\text { has a chronic disease }\end{array}$ & \\
\hline Education $\left(\mathrm{x}_{2}\right)$ & A value that indicates what education the employee received & Low \\
\hline Experience $\left(\mathrm{x}_{3}\right)$ & Displays the length of service of the employee & Medium \\
\hline Age $\left(\mathrm{x}_{4}\right)$ & Displays the age of the employee & High \\
\hline Workload $($ Staffing $)\left(\mathrm{x}_{5}\right)$ & Displays staffing at the pharmacy & \\
\hline Working conditions $\left(\mathrm{x}_{6}\right)$ & Reflects compliance of working conditions with the established norms \\
\hline $\begin{array}{l}\text { Ability to work with } \\
\text { clients }\left(\mathrm{x}_{7}\right)\end{array}$ & The presence of complaints against the employee \\
\hline Trade turnover $\left(\mathrm{x}_{7}\right)$ & Defined as the ratio of employee turnover to pharmacy turnover \\
\hline $\begin{array}{l}\text { Availability of } \\
\text { additional sales }\left(\mathrm{x}_{2}\right)\end{array}$ & Displays the number of items in the check & \\
\hline Average check & Displays the average check amount & \\
\hline $\begin{array}{l}\text { The level of labor } \\
\text { potential of the } \\
\left.\text { employee( } \mathrm{x}_{2}\right)\end{array}$ & The output variable \\
\hline
\end{tabular}

\section{Source: developed by the authors}

The third stage, a fuzzy model of estimating the level of labor potential of the employee has been built [8]. At the same stage, the rules for obtaining the values of the resulting linguistic variable "level of labor potential" 
were developed. For example, the set of solutions is characterized by a set of factors, linguistic variables given on the base sets, respectively (x1, x2,.. x10). Thus, the variable $\mathrm{x} 1$ - "health" can mean "low", "high"

Table 3

Rules for obtaining values of the linguistic variable "labor potential"

\begin{tabular}{|c|c|c|c|c|c|c|c|c|c|c|}
\hline \multicolumn{10}{|c|}{ Components of fuzzy inference rules } & \multirow[t]{2}{*}{ Result "Labor potential" } \\
\hline $\mathrm{x}_{1}$ & $\mathrm{x}_{2}$ & $\mathrm{x}_{3}$ & $\mathrm{X}_{4}$ & $\mathrm{X}_{5}$ & $\mathrm{x}_{6}$ & $\mathrm{x}_{7}$ & $\mathrm{X}_{8}$ & $\mathrm{X}_{9}$ & $\mathrm{x}_{10}$ & \\
\hline $\begin{array}{l}\mathrm{L} \\
\mathrm{M}\end{array}$ & $\mathrm{L}$ & $\mathrm{L}$ & $\begin{array}{l}\mathrm{H} \\
\mathrm{L}\end{array}$ & $\mathrm{L}$ & $\begin{array}{l}\mathrm{L} \\
\mathrm{M}\end{array}$ & $\mathrm{L}$ & $\mathrm{L}$ & $\mathrm{L}$ & $\mathrm{L}$ & $\begin{array}{l}\text { Does not meet the requirements } \\
\text { at all }\end{array}$ \\
\hline $\begin{array}{l}\mathrm{L} \\
\mathrm{M}\end{array}$ & $\begin{array}{l}\mathrm{L} \\
\mathrm{M}\end{array}$ & $\begin{array}{l}\mathrm{L} \\
\mathrm{M}\end{array}$ & $\begin{array}{l}\mathrm{H} \\
\mathrm{M}\end{array}$ & $\begin{array}{l}\mathrm{L} \\
\mathrm{M}\end{array}$ & $\begin{array}{l}\mathrm{M} \\
\mathrm{H}\end{array}$ & $\begin{array}{l}\mathrm{L} \\
\mathrm{M}\end{array}$ & $\mathrm{L}$ & $\mathrm{L}$ & $\begin{array}{l}\mathrm{L} \\
\mathrm{M}\end{array}$ & Does not meet the requirements \\
\hline $\begin{array}{l}\mathrm{M} \\
\mathrm{H}\end{array}$ & $\begin{array}{l}\mathrm{M} \\
\mathrm{H}\end{array}$ & $\begin{array}{l}\mathrm{M} \\
\mathrm{H}\end{array}$ & $\begin{array}{l}\mathrm{M} \\
\mathrm{L} \\
\mathrm{H}\end{array}$ & $\begin{array}{l}\mathrm{M} \\
\mathrm{H}\end{array}$ & $\begin{array}{l}\mathrm{L} \\
\mathrm{H} \\
\mathrm{M} \\
\end{array}$ & $\begin{array}{l}\mathrm{M} \\
\mathrm{H}\end{array}$ & $\begin{array}{l}\mathrm{M} \\
\mathrm{H}\end{array}$ & $\begin{array}{l}\mathrm{L} \\
\mathrm{M}\end{array}$ & $\begin{array}{l}\mathrm{M} \\
\mathrm{H}\end{array}$ & Meets the requirements \\
\hline $\begin{array}{l}\mathrm{M} \\
\mathrm{H}\end{array}$ & $\begin{array}{l}\mathrm{M} \\
\mathrm{H}\end{array}$ & $\begin{array}{l}\mathrm{H} \\
\mathrm{M} \\
\mathrm{L}\end{array}$ & $\begin{array}{l}\mathrm{M} \\
\mathrm{H}\end{array}$ & $\begin{array}{l}\mathrm{M} \\
\mathrm{H}\end{array}$ & $\begin{array}{l}\mathrm{M} \\
\mathrm{H}\end{array}$ & $\mathrm{H}$ & $\begin{array}{l}\mathrm{M} \\
\mathrm{H}\end{array}$ & $\begin{array}{l}\mathrm{M} \\
\mathrm{H}\end{array}$ & $\begin{array}{l}\mathrm{M} \\
\mathrm{H}\end{array}$ & High level of compliance \\
\hline
\end{tabular}

Source: developed by the authors

Based on the developed rules, individual evaluations of employees are determined. The membership function is determined for each linguistic variable. The Mamdani algorithm was used to find the indicator of labor potential. According to the value of the linguistic

Table 4

Individual evaluations of employees

\begin{tabular}{|c|c|c|c|c|}
\hline \multicolumn{5}{|c|}{ Individual evaluations of employees } \\
\hline Employee 1 & Employee 2 & Employee 3 & Employee 4 & Employee 5 \\
\hline $\begin{array}{c}\text { High level } \\
\text { of compliance }\end{array}$ & $\begin{array}{c}\text { Meets } \\
\text { the requirements }\end{array}$ & $\begin{array}{c}\text { Does not meet } \\
\text { the requirements }\end{array}$ & $\begin{array}{c}\text { Does not meet } \\
\text { the requirements at all }\end{array}$ & $\begin{array}{c}\text { Meets } \\
\text { the requirements }\end{array}$ \\
\hline
\end{tabular}

or "medium". The total number of rules for obtaining the values of the linguistic variable "labor potential" is defined as follows ( ), so for this model we rotate only the most important of them (Table 3). variable "labor potential" individual assessments of employees are formed. The higher the rating value, the higher the employee's rating, the lowest the rating value corresponds to the last place in the rating. For example, we give calculations for five employees (Table 4).

\section{Source: calculated by the author}

Thus, the analysis of the results presented in Table 4 allowed us to conclude that the highest score is employee № 1, and the lowest employee №3.

At the fourth stage, scenarios for managing the labor potential of pharmacy network employees were developed. Consider in more detail the process of developing scenarios for managing the labor potential of the employee. To assess the impact of factors on the labor potential of the employee in the dynamics of a simulation experiment using a pulse model. The study of the influence of factors was carried out in the following stages. At the first stage, a contiguity matrix is

Table 5

Matrix of adjacency of cognitive model of influence of factors on labor potential of the employee

\begin{tabular}{|l|c|c|c|c|c|c|c|c|c|c|c|c|}
\hline The name of the factor & 尚 & 1 & 2 & 3 & 4 & 5 & 6 & 7 & 8 & 9 & 10 & 11 \\
\hline Health & 1 & 0 & 0 & 0 & 0 & 0 & 0 & 1 & 0 & 0 & 0 & 1 \\
\hline Education & 2 & 0 & 0 & 0 & 0 & 0 & 1 & 1 & 1 & 0 & 1 & 1 \\
\hline Experience & 3 & 0 & 1 & 0 & 0 & 0 & 0 & 1 & 1 & 1 & 0 & 1 \\
\hline Age & 4 & -1 & 0 & 1 & 0 & 0 & 0 & 0 & 0 & 0 & 0 & 1 \\
\hline Workload (Staffing) & 5 & -1 & 0 & -1 & 0 & 0 & 0 & -1 & 0 & 0 & -1 & -1 \\
\hline Working conditions & 6 & 1 & 0 & 0 & 0 & 0 & 0 & 0 & 0 & 0 & 0 & 1 \\
\hline Ability to work with clients & 7 & 0 & 0 & 0 & 0 & 0 & 0 & 0 & 1 & 0 & 0 & 1 \\
\hline Trade turnover & 8 & 0 & 0 & 0 & 0 & 0 & 0 & 0 & 0 & 0 & 0 & 1 \\
\hline Availability of additional sales & 9 & 0 & 0 & 0 & 0 & 0 & 0 & 0 & 1 & 0 & 1 & 1 \\
\hline Average check & 10 & 0 & 0 & 0 & 0 & 0 & 0 & 0 & 1 & 0 & 0 & 1 \\
\hline Employment potential of the employee & 11 & 0 & 0 & 0 & 0 & 0 & 0 & 0 & 0 & 0 & 0 & 0 \\
\hline
\end{tabular}

Source: developed by the authors constructed for the cognitive model of employee labor potential management, and we define a set of management scenarios. In the second stage, a simulation experiment using a pulse model was performed. At the third stage, the influence of the selected factor on the resulting indicator (labor potential of the employee) in each period of time is determined, as well as the total influence of this factor on the resulting indicator is determined. The matrix of adjacency of the cognitive model of the influence of factors on the labor potential of the employee of the pharmacy network is presented in Table 5. 
The plural of scenarios and their corresponding content are presented in table. 6

The essence of the implementation of the simulation experiment using the pulse model [9] is as follows: the

Table 6

Contents of scenarios for managing the labor potential of the employee

\begin{tabular}{|c|l|l|}
\hline Scenario & \multicolumn{1}{|c|}{ Contents of the management script } & \multicolumn{1}{c|}{ Activities } \\
\hline$S_{1}$ & Improving employee health & Disease prevention (vaccinations, etc.) \\
\hline$S_{2}$ & $\begin{array}{l}\text { Improving the level of education of the } \\
\text { employee }\end{array}$ & Conducting additional trainings and courses \\
\hline$S_{3}$ & Employee motivation & $\begin{array}{l}\text { Wage increases and other methods } \\
\text { of motivation, redistribution of employees } \\
\text { between pharmacies }\end{array}$ \\
\hline$S_{4}$ & Check staffing & $\begin{array}{l}\text { Reducing the burden on the employee } \\
\text { by increasing the staff, revising the work schedule }\end{array}$ \\
\hline$S_{5}$ & Improving working conditions & Ensuring decent working conditions \\
\hline$S_{6}$ & Increasing the employee's trade & Conducting additional seminars and tests \\
\hline$S_{7}$ & $\begin{array}{l}\text { Increasing the percentage of additional } \\
\text { sales }\end{array}$ & $\begin{array}{l}\text { Conducting master classes on the concept of "additional } \\
\text { sales" }\end{array}$ \\
\hline$S_{8}$ & $\begin{array}{l}\text { Increasing the amount of the average } \\
\text { check }\end{array}$ & Conducting additional trainings and refresher courses \\
\hline
\end{tabular}

Source: developed by the author

The impulse vector for each scenario is presented in table 7 .

Table 7

Impulse vector for scenario

\begin{tabular}{|c|l|}
\hline Scenario & Impulse vector \\
\hline$S_{1}$ & $P_{S_{1}}(0)=(1,0,0,0,0,0,0,0,0,0,0)$ \\
\hline$S_{2}$ & $P_{S_{1}}(0)=(0,1,0,0,0,0,0,0,0,0,0)$ \\
\hline$S_{3}$ & $P_{S_{1}}(0)=(0,0,1,0,0,0,0,0,0,0,0)$ \\
\hline$S_{4}$ & $P_{S_{1}}(0)=(0,0,0,1,0,0,0,0,0,0,0)$ \\
\hline$S_{5}$ & $P_{S_{1}}(0)=(0,0,0,0,1,0,0,0,0,0,0)$ \\
\hline$S_{6}$ & $P_{S_{1}}(0)=(0,0,0,0,0,1,0,0,0,0,0)$ \\
\hline$S_{7}$ & $P_{S_{1}}(0)=(0,0,0,0,0,0,0,0,1,0,0)$ \\
\hline$S_{8}$ & $P_{S_{1}}(0)=(0,0,0,0,0,0,0,0,0,1,0)$ \\
\hline
\end{tabular}

Source: developed by the authors

Rule (1) is implemented using MS Excel. Given the initial values, the state of the system at times is determined $t=1, \ldots, 5$. In this study, one year was chosen for the time period. For example, consider several scenarios. The dynamics of the labor potential of the employee in the implementation of the scenario is presented in Fig. 2. value of the corresponding vertex per unit increases, impulse to the top is set and the behavior of the system is analyzed. 


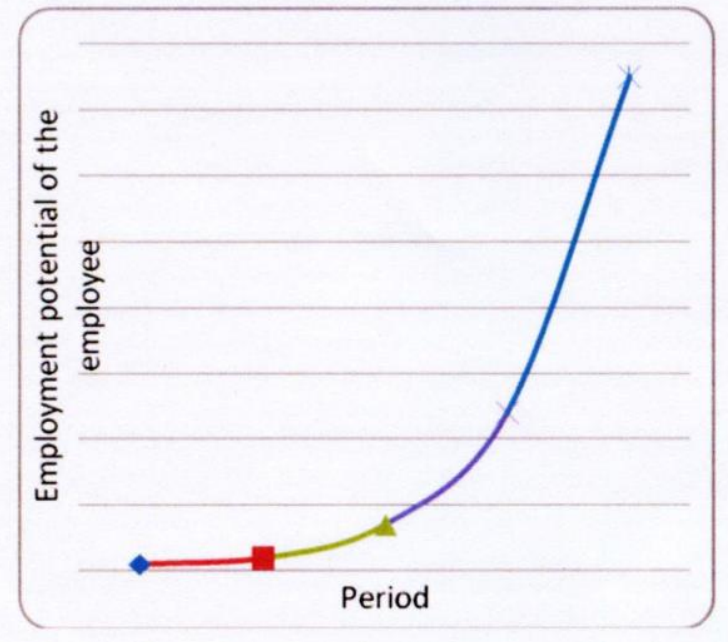

Fig. 2 Change in the labor potential of the employee with an increase in the factor "Level of physical activity" per unit in the model of management of labor potential of the employee.

\section{Source: calculated by the authors}

The analysis of the presented results allows drawing a conclusion that at increase in level of education of the worker, his labor potential will increase. Thus, comparing scenarios, management chooses the scenario with the greatest growth in labor potential.

The proposed approach allows the company's management to make informed decisions about the management of labor potential of an individual employee, but has some shortcomings, does not take into account the effectiveness of scenarios, i.e. the ratio of costs to results. The prospect of further research is to take into account the effectiveness of scenarios in the process of supporting decision-making on the management of labor potential of the employee.

\section{Conclusions}

The use of labor potential of employees is an integral part of the economic activity of the enterprise. The labor potential turns a person into the most important resource of production, which is able to ensure the competitiveness of the enterprise.

The labor potential of the enterprise is the existing and potential opportunities of employees to implement their

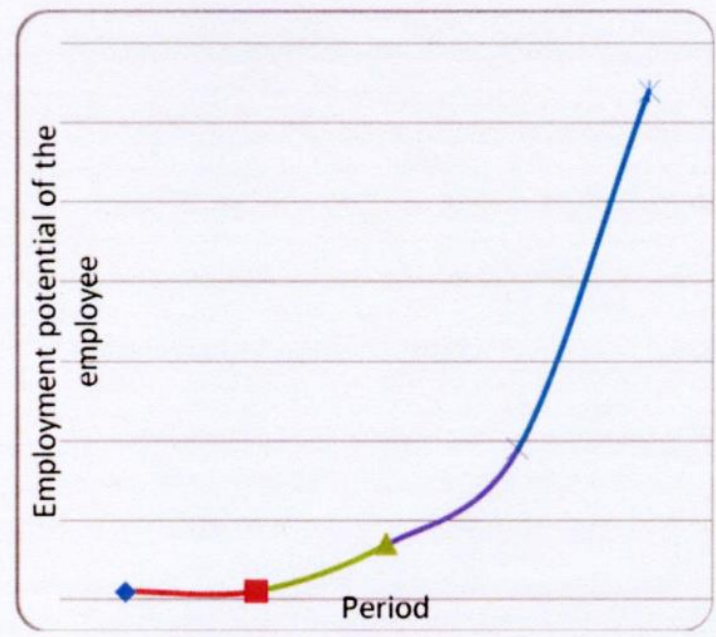

Fig. 3 Change in the labor potential of the employee with increasing factor "Education" per unit in the model management of labor potential of the employee

quantitative and qualitative characteristics in specific socio-economic and production-technical conditions. The following factors of influence on the labor potential of an employee of the pharmacy network are identified: health status, education, experience, age, workload, working conditions, ability to work with customers and the employee's turnover in the pharmacy.

Since most of the factors that affect the work potential of the employee are high quality, we use cognitive modeling and fuzzy mathematics methods to model the process of work potential management.

The paper develops a procedure for managing the labor potential of the employee at the micro level using the methods of cognitive modeling and fuzzy mathematics. The proposed procedure for managing the labor potential of the employee has been tested at the enterprises of the pharmacy network. The developed procedure for managing the level of labor potential of employees can be formed in the framework of decision-making on staff motivation and the possibility of creating publicly available scenarios for managing the labor potential of the employee to increase the efficiency of his work.

\section{References}

1. Blednykh A. Evaluation of the effectiveness of the use of labor potential. Labor economics. Volume 5. 2018. 51-54 p. [in Ukrainian].

2. Melnichuk D. Labor potential in the system of human capitales. THE JOURNAL OF ZHYTOMYR STATE TECHNOLOGICAL UNIVERSITY. SERIES: ECONOMICS

3. Mironova L. Management of labor potential of the enterprise on the basis of the rating approach: monograph / Classical private university. - 2011. 244 p. [in Ukrainian].

4. Shevchenko S. Evaluation of the effectiveness of the use of labor potential.2015 [Access mode]: https://cyberleninka.ru/article/n/otsenka-effektivnosti-ispolzovaniya-trudovogo-potentsiala/viewer[in Ukrainian].

5. Shostak LV, Petrini VA Labor potential as a driving force of effective development of the enterprise. Nikolaev.2019. [in Ukrainian].

6. Makarenko O, Kudievskaya K. Model of motivation of a pharmacy network employee based on the fuzzy conclusion rule of the All-Ukrainian scientific-practical conference "Problems of international migration: assessment and prospects for solution" May 16, 2020. Odessa [in Ukrainian].

7. Kulinich A. Methodology of cognitive modeling of complex ill-defined situations / A.A. Kulinich // Proceedings of the second international conference on management problems. - M.: IPU RAN, 2003. 219-227 p. [in Ukrainian]. 